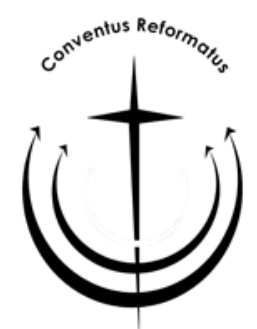

\title{
Philosophical and theological influences in John Calvin's thought: reviewing some research results
}

\author{
B.J. van der Walt \\ School of Philosophy \\ Potchefstroom Campus \\ North-West University \\ POTCHEFSTROOM \\ E-pos: hannah@intekom.co.za
}

\section{Abstract \\ Philosophical and theological influences in John Calvin's thought: reviewing some research results}

A profound thinker like Calvin basically has to answer the following two questions: What "is" and what "ought" to be? The first question deals with what reality looks like, its ontological structure or one's type of thought. The second question concerns one's view of the norms valid for created reality, the direction which one's life takes or the spiritual trend of one's thinking.

In a previous article in the same issue of this journal, Calvin's answer to the second question was already investigated. Among all the spiritual trends of his time, his main motive was to be obedient to God, his Word and his will. We now turn to the answer to the first question: What types of philosophies and theologies emerged within these various spiritual trends which could have influenced Calvin's thinking?

The investigation develops through the following steps. Firstly, the question is posed whether Calvin really succeeded in the direction of his thinking, viz. to be a radical-biblical reformational thinker. This question is divided into three sub-questions: was Calvin influenced by extra-biblical ideas? If so, to what extent? How did he employ pre-Christian insights? The second and main section tries to answer these difficult questions by reviewing seven most prominent philosophical and theological types of thinking. The third section indicates the contribution of a Christian philosophical analysis of his worldview. The con- 
cluding section draws the last lines of Calvin's "intellectual portrait".

\section{Opsomming}

\section{Filosofiese en teologiese invloede op die denke van Johannes Calvyn: 'n bespreking van enkele navorsingsresultate}

'n Diepsinnige denker soos Calvyn behoort die volgende twee basiese vrae te beantwoord: Wat "is" en wat "behoort"? Die eerste vraag handel oor hoe die werklikheid lyk, die ontologiese strukture, of 'n mens se tipe denke. Die tweede vraag het betrekking op 'n mens se visie op die norme wat vir die geskape werklikheid geld, oor die rigting van 'n mens se lewe, of die geestestroming waarbinne iemand dink.

In die vorige artikel in dieselfde nommer van hierdie tydskrif is Calvyn se antwoord op die tweede vraag reeds ondersoek. Onder al die geestestromings van sy tyd was sy hoofmotief om aan God alleen, sy Woord en sy wil gehoorsaam te wees. Hierdie artikel ondersoek sy antwoord op die eerste vraag: Watter soort filosofieë en teologieë, wat in die verskillende geestestromings gestalte gekry het, het moontlik Calvyn se denke beïnvloed?

Die ondersoek word in die volgende stappe ontwikkel. Ten eerste word die vraag gestel of Calvyn werklik volledig geslaag het in die rigting van sy denke, naamlik om 'n radikaal-bybelse reformatoriese denker te wees. Hierdie vraag word in drie subvrae onderverdeel: Was Calvyn beïnvloed deur buite-bybelse insigte? Indien wel, tot watter mate? Hoe het hy hierdie idees gebruik? Die tweede afdeling probeer om hierdie moeilike vrae te beantwoord deur 'n oorsigtelike bespreking van sewe van die mees prominente filosofiese en teologiese tipes denke. Die derde afdeling bespreek die bydrae van 'n Christelik-filosofiese analise van sy lewensvisie. In die afsluitende gedeelte word die laaste buitelyne van Calvyn se "intellektuele portret" getrek.

\section{Introduction}

Before embarking on our topic, some preliminary questions, like the following, should be asked: Did Calvin succeed in his deepest motive to develop a radical-biblical worldview or did he also employ extra-biblical ideas? (The answer to this question is obvious: No thinker can read the Bible without preconceptions. However, because many theologians regard Calvin as a purely biblical thinker, this remains an issue to be discussed.) If so, to what extent and how did he rely on foreign influences? 


\subsection{Calvin's deepest motive: to be a radical-biblical reformer}

The unique character of the Reformation resides not only in the fact that it was anti-synthetic minded (the negative), but especially in its Christian anti-synthetic character (the positive). The Reformation wanted to break with medieval synthetic thought not because of any problems about the biblical element contained in it (which was the motive behind secular anti-synthetic thought), but to free the Word of God, obscured through synthesis with pagan thought. Sola Scriptura was written boldly on the Reformation banner.

This was also the spirit of the great reformer, John Calvin. He, for instance (cf. Calvin, 1559: Institutes, 2.2.4), criticises the church fathers by saying that "... they have come far too close to the [Greek and Roman] philosophers ... they strove to harmonize the doctrine of Scripture halfway with the beliefs of the philosophers" (cf. Calvin, 1960; translation - Battles).

\subsection{Did Calvin succeed?}

Calvin was convinced that the Scriptures should be allowed to speak clearly for themselves and should not be explained allegorically. His reverence towards the Bible (inherited from his humanistic training) prevented him from applying the method of eisegesis and exegesis. Eisegesis-exegesis was one of the methods applied during medieval synthetic thinking (cf. Vollenhoven, 2005a:66-68) to read extrabiblical philosophical ideas into the Bible (= eisegesis) and in this way acquired biblical approval for the unbiblical, pre-Christian Greek philosophical ideas (= exegesis). An example is how the unbiblical dualism of body and soul could receive biblical sanction - resulting in a synthesis between the Bible and ancient anthropologies.

While one should have the greatest appreciation for Calvin's new hermeneutics (discussed extensively by many authors at different Calvin Research Congresses), the question still has to be asked whether he always applied it consistently. No human being can read the Bible without any preconceptions.

In this regard the Calvin scholar Wendel (1963:359), wrote the following:

But sometimes, for the sake of logical coherence or out of attachment to pre-established dogmatic positions, he also did violence to the biblical texts. His principle of Scriptural authority then led him to search the Scriptures for illusionary support, by means of purely arbitrary interpretations ... Although Calvin 
showed himself capable of profiting by the methods of the humanists, and on many occasions gave proof of a sense of history that was rare enough in that epoch, he also knew how to adapt a text to the requirements of his doctrine ... It would be ungracious of us to labour this point. But truth compels one to admit frankly that, despite all his fidelity to the Bible, he seems to have been searching the Scriptures more frequently for texts to support a doctrine accepted in advance than to derive doctrine from the Scriptures.

Is it thus possible that Calvin's efforts towards a scripturally determined worldview sometimes failed, because he went to the Scriptures to find textual support for ideas accepted in advance, while being unaware of the fact that his philosophical preconceptions were not Scriptural.

\subsection{The nature of this investigation}

My preceding article in this journal investigated the religious direction (spiritual trend) of Calvin's thought among other contemporary trends. The conclusion was that Calvin's thinking was motivated by a Christian direction of obedience to God's Word alone. In this respect Calvin was unique, indicating a new way among a chaos of spiritual confusion.

This follow-up article will investigate possible influences on his view of reality (his type of worldview or philosophy). Since direction and type is intimately connected, the major question (as already stated) will now be whether Calvin fully succeeded in applying the Christian direction of his thinking also to its contents. (For a detailed explanation of the distinction between trends and types or direction and structure, cf. Vollenhoven, 2005a:99-115; 2005b; 2005c:xxvii et seq. and Bril \& Boonstra, 2000:38, 401-405.) In this respect, as will become evident, Calvin's ideas were not as novel as he remained stuck in past and contemporary ideas.

To summarise the preceding: The "real Calvin" was not only the non-conformist reformer, who challenged the prevalent notions of his day, striking out a new path (cf. Klapwijk, 1991a:128), but also the Calvin who could not free himself fully from past and contemporary - even unbiblical - influences.

This article on Calvin's intellectual "pedigree" will therefore be of a worldviewish-philosophical nature. The author is of the opinion that such a philosophical approach is in the position to uncover the basic foundations of Calvin's thought. A Christian-reformational philoso- 
phical approach includes the additional advantage that it does not (as e.g. secular approaches) simply rejects Calvin's ideas or deliberately tries to force his thinking into a foreign mold.

\subsection{Important preliminary questions}

The main question about foreign influences in Calvin's thinking may be divided in the following three sub-questions: Was Calvin influenced by extra-biblical ideas?; If so, to what extent?; How did Calvin employ non-biblical insights in his own thinking?

Answering the first question, research has already indicated that there can be no doubt anymore that Calvin also learned, apart from the Bible, much from his contemporary spiritual environment. We will therefore be very brief on this point. My previous research (cf. Van der Walt, 1979; 1991) will not only be updated, but also abbreviated. Only a selection of some of the most important research results will be mentioned to assist (new) Calvin researches.

As will transpire, no definite answer could thus far be provided to the second question, viz. to what extent Calvin was dependent on foreign (e.g. Greek and Roman) philosophical influences. Researchers tend to err either per defectum (denying such influences) or per excessum (over-emphasising them). I also doubt whether this problem will soon be fully answered and a consensus achieved. According to Wendel (1963:359) it will be a gigantic task, requiring the patience of a whole team of researchers.

\subsection{The sense of such an endeavour}

The sense of such an endeavour depends on one's own viewpoint on the correct relation between Christian and non-Christian thinking. When they are regarded as mutually exclusive, it will be important to know to what extent Calvin was also influenced by pre-Christian thinkers. Klapwijk (1973) not only discusses Calvin's own viewpoint in this regard, but he himself (Klapwijk) is of the opinion that the relation between Christian and pre-Christian (secular) thought cannot be simply understood in terms of negation and exclusion. In the light of 2 Corinthians 10:5, a Christian thinker's attitude should, according to Klapwijk, (1973:44, 45, 61 and for the detail Klapwijk, 1991b) be both opposition ("Casting down reasonings and every high thing that is exalted against the knowledge of God ...") and openness ("... and bringing every thought into captivity to the obedience of Christ"). 
This statement leads to the third question. How did Calvin exactly employ extra-biblical ideas in his thinking? In the light of our answers to the first and second questions, this is perhaps the most important and also more attainable issue to be researched (see 2.5).

\section{The most prominent philosophies and theologies in Calvin's time}

We will look for clues to the above questions in the brief review of the following possible influences on Calvin: patristic theology, medieval theology, Platonism, Stoicism, Humanism, Anabaptism and the ideas of Calvin's co-reformers. Of some assistance in this regard is the study of Mooi (1965), since he provides details of the thinkers quoted by Calvin as well as in which works Calvin referred to them.

For readers primarily interested in the possible influence of theological trends on Calvin, Balke (1982) gives a survey under the following three main headings: romanism (inter alia Thomas Aquinas, Duns Scotus, William of Occam, mysticism, devotio moderna, and biblical humanism), reformation (Luther, Melanchthon, Zwingli, Bucer) and radicalism (the Anabaptists, Libertines and Anti-trinitarians).

\subsection{Patristic influences}

In the discussion of the third synthesis (cf. 3.3 of my previous article; p. 32) it was pointed out that both the pre-Reformation and earlier Humanism, although with different motives, reached back to patristic thought. In Calvin's time, too, interest in this area remained alive with various groups (cf. Lane, 1999). According to Todd (1971), Calvin only started evincing his great interest in the writings of the patres (of which the first edition of his Institutes in 1536 already gives clear proof) after the writing of his commentary on the De Clementia of Seneca (1532) - that is, after his conversion to protestantism.

\subsubsection{Why Calvin showed appreciation}

Calvin attached great importance to the work of the church fathers, because he regarded them as representatives of a purer era in the history of Christendom, closer to the biblical source, and thus still relatively free of the pollution of all kinds of fallible, human thought. Calvin, for example, did not regard Augustine as a Christian neoPlatonist, but the church leader who, towards the end of his life, understood the Bible even better and thus repudiated many of his own earlier ideas. The Bishop of Hippo was for the reformer of 
Geneva primarily a guide to the Word of God, and his writings a means by which the living Source could once more be reached.

Especially two church fathers were held in high esteem by Calvin. Augustine was Calvin's guide in systematic theology (cf. Lange van Ravenswaay, 1990) and Chrysostom his model for biblical exegesis (cf. Nauta, 1976:79; Saxer, 1984:102; Ganoczy \& Müller, 1981).

\subsubsection{Especially Augustine}

Particularly the influence of the church father Augustine on Calvin was great. Smits (1957-1958) points out meticulously the extent to which Calvin borrowed from Augustine. The total number of references to Augustine in Calvin's Institutes (1559 edition) as identified by Smits runs to 1175 . For all Calvin's works this number comes to 4119 (cf. also Mooi, 1965). Snell (1968) elaborates on Smits' work and looks at important questions such as the following: Is there a fundamental continuity between the reformer of Geneva and the Bishop of Hippo? Exactly in what sense was Augustine a source in Calvin's thought?

The following general conclusion can be drawn: As far as their theologies revealed faithfulness to the Scriptures, Calvin was willing to listen to the early fathers, especially Chrysostom and Augustine.

\subsection{The influence of medieval thought}

Because Calvin's oppositon to the Catholic Church is well-known (cf. e.g. Zachmann, 2008), it will not be dealt with separately. The focus here is on the possible theological-philosophical influences of various medieval thinkers.

Calvin himself provides evidence of having read thinkers like Anselm, Peter Lombard, Thomas Aquinas, Duns Scotus and William of Occam. To a large extent, however, their precise influence on Calvin is still a controversial matter. Furthermore no comprehensive picture has emerged as different researchers focused on different medieval theologians' influence on Calvin - and sometimes tend to overemphasise the influence of that particular person.

\subsubsection{Late-medieval influence}

More recently especially the influence of late-medieval thinking (via moderna, devotio moderna and Duns Scotus) was emphasised. Earlier Reuter (1963) already drew attention to the influence of Scotus. But, according to Gamble (1994:97), on this specific topic the 
secondary literature exhibits a continuing debate which will not soon be concluded.

\subsubsection{Persistent influence of medieval dualism}

As the result of a general antipathy against medieval scholasticism at the time of Calvin, research revealed mostly a negative attitude also in Calvin towards synthetic medieval thinking (for the specific studies, cf. Van der Walt, 1991:231-233). At the same time (cf. Van der Walt, 1991:232), however, reformational thinkers like Dooyeweerd and Vollenhoven indicate that Calvin - in spite of his reaction against medieval thought - sometimes (in, e.g. his doctrine of two kingdoms) remained stuck in scholasticism. On the one hand Klapwijk (1991a:128) agrees that Calvin sometimes reverts to the scholastic medieval doctrine of nature-supernature. On the other hand he (cf. Klapwijk, 1991a:131) is of the opinion that Calvin largely freed himself from this dualism.

\subsection{Platonism and neo-Platonism}

In a previous review I (Van der Walt, 1991:233-234) indicate how some researchers underestimated the Platonic influences on Calvin, while others completely overestimated them. Most of the research, however, acknowledges the unmistakable influence of Plato on especially Calvin's anthropology. We will confine ourselves here to a few remarks about the more balanced viewpoint of Babelotzky (1977; cf. also Van der Merwe, 1982).

\subsubsection{How it happened}

Babelotzky (1977) first describes the revival of Plato's philosophy and Platonism in France at the beginning of the sixteenth century and then carefully studies Calvin's training at various centres to determine how, where and when he could have encountered these schools of thought. He then mentions all the references to Plato in Calvin's Institutes (final edition of 1559). Then follows the main course of his book: Platonic images and trains of thought in Calvin's view of the human being.

Babelotzky (1977) points out how Plato (in opposition to Aristotle, the teacher of natural science) was regarded as the authority in theology in Calvin's time. As Plato was the current fashion, nobody needed to be embarrassed or to justify himself for being a Platonist (Babelotzky, 1977:35). Platonic ideas runs through the thought of the reformer of Geneva like a red thread (Babelotzky, 1977:85, 89). 
Babelotzky $(1977: 142,212)$ also points out that Calvin definitely underwent direct influence from Plato and not via secondary sources or neo-Platonism. He indicates which works of Plato contributed most in this respect. Furthermore, Plato's influence on Calvin was not only formal (language usage), but he also influenced the contents, especially that of Calvin's anthropology: “... our entire study has revealed that many Platonic conceptions influenced Calvin not merely superficially and as regards certain points - they penetrated deeply into the structure and content of his thought and accompanied him a long way" (Babelotzky, 1977:260; translation BJvdW).

\subsubsection{The result}

Painstakingly Babelotzky (1977) furthermore points out not only similarities but also differences between Plato and Calvin. He is thus of the opinion that it would be incorrect to call Calvin a "Platonist". This would presuppose a master-student relationship which did not in this instance exist. Calvin remained his own master. He took what he could use from Plato without in the least becoming subservient.

To my mind it would therefore be more appropriate to describe Calvin, especially in his anthropology, as a Platonising thinker, rather than as a Platonist. A Platonist is someone who directly follows Plato's ideas, while a Platonising thinker does not follow Plato completely, but combines themes from his philosophy with structurally different ideas.

\subsection{Stoicism}

In my survey (cf. Van der Walt, 1979; 1991) I mention many sources on the revival of stoic philosophy in Calvin's time, and also indicate two extreme viewpoints. On the one hand, those who claim that Calvin's ideas boiled down to no more than "baptised" stoicism and, on the other hand, those who claim that his thoughts were completely free of biblically foreign stoic influences.

\subsubsection{Stoic influences cannot be denied}

In my view the following general conclusion of Battles and Hugo (1969:46, 47) still holds water:

Let us establish, first of all, that the term 'influenced' can bear many shades of meaning; and let us establish further, that it would have been contrary to all experience of a zealous young student who occupied himself so many months with Seneca, 
and eventually wrote a passionate defence of Seneca, and composed a lengthy commentary on Seneca, without being in the least touched, or charmed, or impressed - in short, without being in the least influenced by anything Seneca had ever written. The supposition is too absurd to merit any further discussion.

\subsubsection{Especially in Calvin's ideas of lex naturalis}

One has of course to keep in mind the fact that Calvin wrote his commentary on Seneca's De Clementia during his "pagan apprenticeship", before his conversion to protestantism and the publication of his Institutes. The Calvin we meet here is still the "pre-Calvinist" Calvin. In spite of this, in my own research on Calvin (cf. Van der Walt, 2010a) I trace definite stoic influences in especially his idea of natural law (lex naturalis). The Logos (baptised as God) creates logoi spermatikoi (seeds of himself) in creation which enables the logos (human reason) to know God's will.

\subsection{How Calvin used classical (Greek and Roman) philosophy in general}

Before we discuss possible other influences, we first have to deal with the question of Calvin's attitude towards classical philosophy in general: How did he employ it? For more general surveys the reader is referred to the studies of Klapwijk (1983) and Partee (1983).

\subsubsection{Partee's and Nuovo's viewpoints}

According to Partee (1977:13) Calvin did not condemn or sanction the classical philosophers, but he rather transformed them. Their points of view did not determine Calvin's thought, but contributed to it, because he did not regard these as a source of truth but rather as additional explicatory material of his own viewpoint (cf. Partee, 1977:91). Thus Calvin's use of the classics is eclectic and unsystematic. His treatment of philosophical insights appears in the context of his exposition of Christian faith and not in the form of a sustained argumentation, with the purpose of treating or condoning an entire philosophy systematically (cf. Partee, 1977:95).

Partee's final conclusion reads:

Without doubt Calvin's knowledge of classical philosophy influenced his thinking. It would be a mistake, therefore, to dismiss Calvin's references to philosophy as an inconsequential residue of his early humanistic training ... But it is important to 
recognize that Calvin's use of philosophy is historical rather than systematic. Thus Calvin looks to philosophy for illustration of the truth rather than as a guide to it. (Partee, 1977:146.)

Earlier on Nuovo (1964) came to more or less the same conclusion (cf. also Klapwijk, 1973 quoted under 1.5). According to him the reformer's attitude towards Greek and Roman antiquity can be recapitulated in both the concepts of rejection and dependence. Calvin's "synthesis" of the Bible and antiquity is illustrated by Nuovo by means of specific themes from Calvin's thought. It is also indicated further that Calvin's style to a large extent is derived from antiquity and more specifically from stoic thought.

\subsubsection{Not merely a "formal" use of pre-Christian ideas}

I agree with Partee's and Nuovo's conclusion about the way or how Calvin mainly employed ancient, pre-Christian philosophies, namely mostly eclectic as explanations or illustrations of his own viewpoint. Both authors, however, give the impression that, because Calvin used biblically foreign thinking in this more formal way, the contents of his thinking could not really be contaminated. On this point I disagree. Also Calvin's view of reality (the contents of his worldview) was influenced by extra-biblical sources.

\subsection{Humanism}

Since my previous review of literature (Van der Walt, 1979) I have read many older and more recent books on this aspect of Calvin's thought. A few of them are Breen (1968), Wendel (1976), McGrath (1988:27-49) and especially Bouwsma (1988). The latter convincingly indicates that Calvin was a typically humanist thinker (cf. also the critique on Bouwsma's book in Hesselink, 1994:209-213).

My earlier general conclusion was confirmed:

Calvin inherited neither synthetic thought nor the concept of repristination from early Humanism. He did learn a great deal from later Humanism as regards formal matters such as language, style, hermeneutics, etc. The most fundamental tendency of Humanism was, however, definitely alien to Calvin's intentions - Calvin wanted to prostrate himself before the Word of God in real humility and obedience. (Van der Walt, 1991:236.)

Of course it has to be kept in mind that the concept humanism had a much wider meaning in Calvin's day than it has today, without the anti-Christian associations it contains at present (cf. Boisset, 1959). 
Finally, a brief look at possible contemporary influences on Calvin's thinking: the so-called left wing of the Reformation and his coreformers.

\subsection{Influences of the "left wing" of the Reformation}

In this context I include various trends at the time in which Calvin lived, such as the Anabaptists, Anti-trinitarians, Libertines, et cetera (cf. Estep, 1975; Williams \& Mergal, 1957). Regarding these sixteenth-century trends, more research has been done than before, but definitely not yet enough. In this respect too, these groups can be called the "stepchildren of the Reformation". There are those today who regard them as saints - the real (radical) reformers of the sixteenth century. Others (such as most of the sixteenth century reformers and their contemporary followers) prefer to regard them as heretics and fanatics. This is the reason why they were persecuted and many of their writings confiscated and burnt with them. Since the Second World War, however, pioneering work has been done to make available original writings from these circles. This will definitely contribute to a more objective study of these diverse trends.

Calvin's attitude towards these different currents can be deduced from his own as well as various secondary writings. Helpful are, for instance, the works of Balke $(1977 ; 1982)$ and Stadtland-Neumann (1966).

In general it may be said that Calvin assimilated some positive elements of the Anabaptists' teachings (e.g. the sanctification of life, and freedom of the church from the state). He also approached the radical front of the Libertines with more understanding than other reformers did. However, his struggle against the Anti-trinitarians was without any compromise and even violent (cf. the case of Servet).

\subsection{The influence of other reformers}

It seems as if in this area researchers have reached consensus about the influence of fellow-reformers on Calvin's thinking (cf. e.g. Balke, 1982:57-63). Calvin was considerably younger than most of the other great reformers such as Luther, Zwingli, Melanchthon and Bucer, so he could encounter them and their writings in his formative years.

Without any doubt Luther's books had a great influence on the young Calvin (cf. e.g. Van 't Spijker, 1986a). Bucer, too, had a con- 
siderable influence on Calvin's intellectual development (Van 't Spijker, 1986b). Also Zwingli's influence was documented (cf. Büsser, 1985; 1986; Locher, 1979; 1981). In turn Calvin also influenced younger reformers.

\subsection{Resúme}

To summarise and pinpoint the above influences on Calvin's worldview: He was influenced in dogmatics (systematic theology) especially by Augustine and in his exegesis and preaching to a great extent by Chrysostom; he modified the medieval two-realm doctrine of nature and super-nature; he inherited a Platonising anthropology; in his idea of a lex naturalis he was indebted to stoicism; like the Humanists, he treated ancient texts, the Bible included, with respect and let them speak for themselves (a historico-philological hermeneutics); from the Anabaptists he adopted some positive elements, like the separation between church and state; and from fellow-reformers he also accepted different insights.

\subsection{Conclusion}

What then should be our final conclusion?

\subsubsection{Calvin an independent thinker}

After a study of possible extra-biblical influences on Calvin's thought, the following general conclusion of the earlier Strasbourg Calvin expert, Wendel, can be accepted:

... whatever relations can be established between Calvin and his predecessors, they are not those of a disciple eager to reproduce the thought of his masters and alarmed at the very thought of changing the smallest feature of it. From his very first publication he showed his independence ... This somewhat lofty independence he maintained throughout, even towards authors from whom he borrowed with both hands, such as Luther, Augustine and Bucer ... But these borrowings take on another colour under his pen; they are, as it were, suffused by another light ... Calvin remained himself (Wendel, 1963:10-11).

Van Genderen (1965:45) furthermore reminds us about the following in Calvin's Institutes:

It is not possible to reduce Calvin's Institutes to these (extrabiblical) sources. The number of citations runs into the hundreds - but this is not nearly as many as the number of biblical texts quoted. (Translation - BJvdW.) 


\subsubsection{Calvin also a child of his times}

On the other hand, however, it cannot be denied that whoever reads Calvin's literary output honestly, together with an intimate knowledge of the preceding history of Western thought, will have to admit that this great Frenchman from Noyon often leant on extra-biblical sources. Like any other individual he belonged to his time. He could alienate himself from many undesirable inheritances, but he was also steeped in the thought of his time. (Cf. Schutte (2008:252), who reminds us that Calvin remains an example of faith for us today, but that we should also remember that he lived and wrote long ago in a totally different environment.)

I see the value of this brief survey of secondary sources in the fact that it indicates very clearly that Calvin's thought can only be fathomed in depth and really appreciated when it is viewed against the intellectual décor of his time. Such an approach is in agreement with Calvin's own attitude of semper reformanda, viz. that we should not accept everything he has said and written without applying the Bible as final test. Only in such a critical attitude will we be able to detect the biblically foreign influences, at the same time appreciating his unique biblical stance in the greatest part of his work.

\subsubsection{A reminder about Calvin's major motive}

It should be unfair (because of influences outside the Bible) to characterise Calvin as a synthetic thinker. Bril and Boonstra (2000:393) rightly distinguish between thinkers who purposefully strived at a synthesis or compromise between biblical and non-biblical ideas, and those who resisted such an approach and fought against the spirits of their times. Calvin was a representative of the last attitude (cf. 1.1). Negatively stated, he thought anti-synthetically, and positively formulated, he thought Biblically.

According to Klapwijk (1994:100) Calvin could have followed the following approaches towards non-Christian philosophies: uncritical acceptance, outright rejection or a compromise between pagan and biblical thinking. He, however, opted for none of them. Stated in the image of a house, he realised that ancient pagan philosophy is not a house in which a Christian can breathe and live. Neither is it a house to be completely demolished. Nor a building of which some parts can be left untouched, while other parts have to be pulled down. Instead, Calvin in humility carefully, but never uncritically, listened to the philosophical voices from the past. 


\subsection{A major deficiency}

A deficiency of this article is that the question about extra-biblical influences on Calvin is answered on the authority of secondary research on Calvin. To substantiate all the different influences with adequate documentation from Calvin's Opera would, however, be impossible within the scope of an article or even a whole book. In the following section I will only provide a suggestion how the reformer's worldview may be analysed from a Christian-philosophical perspective.

\section{The contribution of a Christian philosophy in analysing Calvin's Christian worldview}

The three main points of this last section are a brief philosophical evaluation, a more detailed philosophical analysis, and its practical implications for understanding Calvin's Christian doctrines.

\subsection{In a nutshell}

The preceding pages may be summarised by saying that two different lines can be detected in Calvin's thinking: a basic biblical (religious) direction (or trend) which is intertwined with a structural analysis of reality (his type of worldview) often borrowed from extrabiblical sources (cf. 1.2 (p. 26) of my preceding article for the distinction).

Fowler (1984:340) evaluates Calvin's thinking as follows:

... candid and careful study of his writings put a very large question mark against the idea that the only flaws in his thought are incidental blemishes that mar a work that is fundamentally pure biblical thought. That there is a powerful biblical stream in Calvin's thought is not denied, but it is suggested that mingling with this biblical stream throughout his work there is another stream of thought which has quite different religious origins.

Like all previous and contemporary Christian reformational thinkers, Calvin's basic motive to think Biblically or anti-synthetically was not fully realised. He, for instance, was not always aware of the fact that one should not only reject the implications of non-biblical Greek and Roman philosophies, but also their deeper religious starting points. His Christian orientation did not always and fully challenge the apostatic religious presuppositions underlying their view of reality and the human being. 
Fowler (1984:340) describes the result in the following way:

There appears in Calvin's thought a fundamental dualism that cannot be explained in terms of remnants of non-Christian ideas clinging to a basically pure stream of Biblical thought. It is a dualism that results from an attempt to synthesize antithetical religious principles.

Clear proof of this is the dualism of the two-realm doctrine which (in the form of the theory of two kingdoms) still played a prominent role in Calvin's thinking (cf. Van der Walt, 2010a:95-104).

\subsection{A more detailed Christian-philosophical analysis of Calvin's worldview}

Philosophy is not by nature a secular enterprise, neither is theology always Christian in nature. A Christian (reformational) philosophy is available since the thirties of the previous century. Such a Christian philosophy enables one to provide a sympathetic analysis of Calvin's worldview. The method I therefore propose is Vollenhoven's problem-historical approach of philosophic historiography. Limited space does not allow me to explain this method (cf. Vollenhoven, 2005a; 2005b; Bril \& Boonstra, 2000; Van der Walt, 2006; 2010c).

Vollenhoven indicated the spiritual direction or trend of Calvin's thinking, namely that he wanted to derive his normative direction from God's Word. Vollenhoven, however, did not describe the type of Calvin's philosophy. As indicated previously (cf. 1.2 of my previous article, p. 26) a trend/current indicates a philosopher's view of the law or what ought to be done. (Calvin wanted to obey God's ordinations.) The type of philosophy in addition explains what is, the ontological structures of reality.

Van der Walt (cf. 1974:339 et seq.) employed Vollenhoven's method to uncover Calvin's ontological philosophical viewpoints. Bril and Boonstra (2000:282-284), in turn, used Van der Walt's research combined with other Calvin studies of a philosophical nature, to decide on Calvin's systematic position (type of philosophy). Two new studies by Van der Walt (2010a; 2010b) provide the details of such a Christian-philosophical analysis of Calvin. The limited space here only allows the following brief summary.

\subsection{The essential elements}

The results of the above-mentioned research boils down to the following philosophical characterisation of Calvin's thought. 
- Calvin was not a mythologising or cosmogono-cosmological, but (in so far as he still thought in a synthetic way) a purely cosmological thinker. As a biblical thinker he, however, did not exclude God from his thinking. Simultaneuosly he disliked any speculation about God which pretends to know more about God than Scripture reveals.

- Calvin rejected individualism as well as universalism and accepted a partial-universalistic viewpoint. Calvin made use of a macrocosmos-microcosmos theory (Macro = God; micro $=$ human beings). This, in spite of the fact that such a theory is usually not found in Calvin's type of philosophy (purely cosmological, dualistic and a vertical partial universalism). It usually occurs in cosmogono-cosmological philosophies (with a horizontal partial universalism), which leads to an analogy between the universal world, godhead or God and the individual human being (cf. Bril \& Boonstra, 2000:354-356).

- Calvin rejected monism (the idea that reality is an original unity) and adhered to a dualistic ontology. According to him reality consists of a transcendent part, God and a non-transcendent part, creation. Neither monism nor dualism is, however, in harmony with the Scriptures. Monism can only be true if we erase the distinction between God and creation. Dualism proposes two separate parts in reality, whereas the Bible teaches God as the Origin of everything that exists.

- Calvin's view of the human being follows his ontological dualism: he proposed a clearly dichotomist anthropology of body and soul/spirit as two separate entities.

- Among the great variety of dichotomist anthropologies, Calvin's viewpoint can be characterised as semi-mystical. Semi-mysticism teaches that human beings are not completely non-transcendent creatures, but also contains a transcendent element (the soul/spirit). Thus the borderline between the transcendent God and man is not perceived to be above but inside human beings.

- According to Calvin the human soul is of divine origin. He can be called a creatianist - God creates a soul for every new human person. After death the soul/spirit again returns to its Origin. (Creatianism should be distinguished from creationism, the viewpoint which inter alia teaches that God created the world in six days of 24 hours.) 
- Among the different types of semi-mysticism, Calvin accepted a Platonising form - certain themes from Plato are included and combined with other philosophical and biblical ideas in his view of the person.

\subsection{Some practical implications}

What is the practical value of such a Christian-philosophical portrait of Calvin? Can it, for example, assist theologians to better understand Calvin's Christian doctrines? Brill and Boonstra (2000:262 et seq.) answer affirmatively. A few examples may illustrate the implications of the above philosophical characterisation of Calvin.

- A purely cosmological kind of philosophy tends towards a philosophy which emphasise the static nature of creation. Anthropologically it can lead to aquiescense and passivity on the side of the human being. This has implications for how one views the relationship between God's sovereignity and human responsibility, and thus for the whole debate about election.

- The type of partial universalism Calvin advocated does not allow to distinguish clearly enough between the nature of the Creator and his creation, especially human beings who are viewed as semi-divine.

- As already indicated, neither monism nor Calvin's ontological dualism can be scripturally acceptable viewpoints. Monism easily leads to pantheism, while dualism can result in deism. One should distinguish between God (the only Origin), his creation and his laws which govern all creatures. Thus, a three-factor ontology, instead of Calvin's two-factor ontology in which only God and cosmos was distinguished, but God's laws (creational ordinances) as a separate entity did not receive enough emphasis inter alia because of the influence of the stoic logos speculation on Calvin's idea of lex naturalis.

- A dichotomist and creatianist anthropology encounters many problems. For instance, when does God create the soul of every human being? For some people the answer to this question will determine whether abortion is to be regarded as murder of a human being. If God creates a soul, even in the case of illegitimate sexual relations and rape, is He not acting against his own commandments? How should a creatianist explain original sin? Biblically speaking he cannot say that God creates sinful souls. Neither will it be Biblically correct to believe that sin only resides 
in the human body - according to the Bible it originates in the human heart.

- Semi-mysticism, according to Bril and Boonstra (2000:368 ff., $386 \mathrm{ff}$., $399 \mathrm{ff}$.), furthermore encouraged all kinds of speculations about God's predestination (viewed as divine determinism) and human responsibility (interpreted as passivity) - especially in Orthodox Protestantism, following Calvin. This debate is continuing up to this day (cf. Muller, 2008).

- Many more examples of how deep philosophical presuppositions determine one's viewpoints as an ordinary Christian or scientific theologian can be enumerated. Different philosophical startingpoints explain why Calvin and the Anabaptists differed on child/ adult baptism as well as other doctrines. Such presuppositions also explain why the reformers not only disagreed with the Catholic viewpoint on the Holy Communion, but why even Luther, Zwingli and Calvin could not agree about the nature of this sacrament (cf. the study by Van 't Spijker et al., 1980).

How Calvin's deepest philosophical presuppositions determined his theological viewpoints and even ecclesiastical practices thus open a huge and fertile new area for future Calvin research.

\section{A final conclusion about the real Calvin}

We have tried to paint only one aspect of a Calvin portrait: the intellectual side of his life and work. It became clear that he was a real historical person, who imbibed different spiritual currents, philosophies and theologies in his thinking.

\subsection{Calvin to be studied more comprehensively}

Apart from a thinking person, Calvin was also a man of flesh and blood. Bouwsma (1988) tried to get "inside" Calvin's personality to understand his emotional life. Others have studied his use of language. Calvin research, however, should not stop at this point. What, for example, about the political, social, economic, judicial, ethical and other aspects of his personality? These should be investigated in more detail in future in order to arrive at a more detailed portrait of this reformer. 


\subsection{Calvin's deepest secret}

Even when all these facets of this formidable person have been investigated, one should not forget that God created human beings with a heart, their religious center, the wellspring of life (Prov. 4:23).

We have indicated in the preceding article that the central thrust of the Reformation was not conversion to the past or to other people's ideas, but conversion to God, his Word and his commandments. This deep, religious direction also fully applies to Calvin's thinking. He did not primarily orientate himself towards the past, or contemporaries around him, or looked in a subjectivist way for guidance in his inner self, or was motivated by a future utopia. The deepest and dominating motive of his entire life was obedience to God, his Word and Will. Even if he could not consistently apply this direction of his life to the contents of his thought - an impossible achievement for sinful human beings - we should appreciate his immense contribution. In spite of all that was said above, Calvin still deserves the honour to be called the father of our reformational tradition.

In the light of the threatening persecution during his early life, this basic religious motive acquired an even greater urgency in Calvin. Oberman (1994:153) explains:

Persecution made Calvin read the Scriptures anew and allowed him to discover God ... At the center ... stands the ... growing insight of the life-giving refuge with God.

\section{List of references}

BABELOTZKY, G. 1977. Platonische Bilder und Gedankengänge in Calvins Lehre vom Menschen. Wiesbaden: Steiner.

BALKE, W. 1977. Calvijn en de Doperse radikalen. Amsterdam: Ton Bolland.

BALKE, W. 1982. Calvin and the theological trends of his time. (In Van der Walt, B.J., ed. Calvinus reformator. Potchefstroom: Institute for Reformational Studies. p. 48-68.)

BATTLES, F.L. \& HUGO, A.M. 1969. Calvin's commentary on Seneca's De Clementia. Leiden: Brill.

BOISSET, J. 1959. Sagesse et sainteté dans la pensée de Jean Calvin: essay sur l'humanisme du réformateur francais. Paris: Presses Universitaires de France.

BOUWSMA, W.J. 1988. John Calvin, a sixteenth-century portrait. New York: Oxford University Press.

BREEN, Q. 1968. Christianity and humanism. Grand Rapids: Eerdmans.

BRIL, K.A. \& BOONSTRA, P.J., reds. 2000. D.H. Th. Vollenhoven: Schematische kaarten: filosofische concepties in probleemhistorisch verband. Amstelveen: De Zaak Haes. 
BÜSSER, F. 1985. Wurzeln der Reformation in Zürich zum 500: Geburtstag der Reformators Huldrych Zwingli. Leiden: Brill.

BÜSSER, F. 1986. The Zurich theology in Calvin's Institutes. (In Van der Walt, B.J., ed. John Calvin's Institutes, his opus magnum. Potchefstroom: Institute for Reformational Studies. p. 133-147.)

CALVIN, J. 1960. Institutes of the Christian religion. (2 vols.) Trans. by F.L. Battles and ed. by J.T. McNeill. Philadelphia: Westminster.

ESTEP, W.R. 1975. The Anabaptist story. Grand Rapids: Eerdmans.

FOWLER, S. 1984. The persistent dualism in Calvin's thought. (In Van der Walt, B.J., ed. Our reformational tradition: a rich heritage and lasting vocation. Potchefstroom: Institute for Reformational Studies. p. 339-352.)

GAMBLE, R.C. 1994. Current trends in Calvin research, 1982-1990. (In Neuser, W.H., ed. Calvinus Sacrae Scripturae professor: Calvin as confessor of Holy Scripture. International Congress on Calvin Research, 20-23 Aug. 1990. Grand Rapids: Eerdmans. p. 91-112.)

GANOCZY, A. \& MÜLLER, K. 1981. Calvins handschriftliche Annotationen zu Chrysostomus: ein Beitrag zur Hermeneutik Calvins. Wiesbaden: Steiner.

HESSELINK, J. 1994. Reactions to Bouwsma's portrait of John Calvin. (In Neuser, W.H., ed. Calvinus Sacrae Scripturae professor. Grand Rapids: Eerdmans. p. 209-213.)

KLAPWIJK, J. 1973. Calvin and Neo-Calvinism on non-Christian philosophy. Philosophia reformata, 38:43-61.

KLAPWIJK, J. 1983. Rationality in the Dutch neo-Calvinist tradition. (In Hart, H., Van der Hoeven, J. \& Wolterstorff, N., eds. Rationality in the Calvinian tradition. Lanham: University Press of America. p. 93-112.)

KLAPWIJK, J. 1991a. John Calvin (1509-1564). (In Klapwijk, J., Griffioen, S. \& Groenewoud, G., eds. Bringing into captivity every thought. Lanham: University Press of America. p. 123-141.)

KLAPWIJK, J. 1991b. The idea of transformational philosophy. (In Klapwijk, J., Griffioen, S. \& Groenewoud, G., eds. Bringing into captivity every thought. Lanham: University Press of America. p. 241-266.)

KLAPWIJK, J. 1994. Calvijn over de wijsbegeerte: oefening in ootmoedigheid. (In Zijlstra, A. \& Doornebal, R.J.A., reds. Christelijke filosofie in beweging. Amsterdam: Buijten \& Schipperheijn. p. 62-100.)

LANE, A.N.S. 1999. John Calvin: student of the church fathers. Edinburgh: Clark.

LANGE VAN RAVENSWAAY, J.M.J. 1990. Augustinus totus noster: das Augustin-Verständnis bei Johannes Calvin. Göttingen: Vandenhoeck \& Ruprecht.

LOCHER, G.W. 1979. Die Zwinglische Reformation im Rahmen der europaïsche Kirchengeschichte. Göttingen: VandenHoek \& Ruprecht.

LOCHER, G.W. 1981. Zwingli's thought: new perspectives. Leiden: Brill.

MCGRATH, A. 1988. Reformation thought: an introduction. Oxford: Blackwell.

MOOI, R.J. 1965. Het kerk- en dogmahistorish element in de werken van Johannes Calvijn. Wageningen: Veenman.

MULLER, R.A. 2008. Christ and the decree: Christology and predestination in reformed theology from Calvin to Perkins. Grand Rapids: Baker Academic.

NAUTA, D. 1976. Stand der Calvinforschung. (In Neuser, W.H., ed. Calvinis theologus: European Congress on Calvin's Research, 16-19 Sept. 1974. Neukirchen-Vluyn: Neukirchener Verlag. p. 71-84.) 
NUOVO, V.L. 1964. Calvin's theology: a study of its sources in classical antiquity. Ann Arbor: University Microfilms.

OBERMAN, H.O. 1994. Initia Calvini: the matrix of Calvin's reformation. (In Neuser, W.H., ed. Calvinus Sacra Scripturae professor: Calvin as confessor of Holy Scripture. Grand Rapids: Eerdmans. p. 113-154.)

PARTEE, C. 1977. Calvin and classical philosophy. Leiden: Brill.

PARTEE, C. 1983. Calvin, Calvinism and rationality. (In Hart, H., Van der Hoeven, J. \& Wolterstorff, N., eds. Rationality in the Calvinian tradition. Lanham: University Press of America. p. 1-16.)

REUTER, K. 1963. Das Grundverständnis der Theologie Calvins unter Einbeziehung ihrer geschichtliche Abhängigkeiten. Neurkirchen: Neurkirchener Verlag.

SAXER, E. 1984. Hauptprobleme der Calvinforschung - Forschungsbericht: 1974-1982. (In Neuser, W.H., ed. Calvinus ecclesiae Genevensis custos. International Congress on Calvin Research, 6-9 Sept. 1982. Frankfurt am Main: Peter Lang. p. 93-112.)

SCHUTTE, G.J. 2008. Hoe Calvinistisch was Nederland? Radix, 34(4):244-253.

SMITS, L. 1957-1958. Saint Augustin dans l'oeuvre de Jean Calvin. (2 vols.) Assen: Van Gorcum.

SNELL, W.F. 1968. The place of Augustine in Calvin's concept of righteousness. Ann Arbor: University Microfilms.

STADTLAND-NEUMANN, H. 1966. Evangelische Radikalismen in der Sicht Calvins. Neukirchen-Vluyn: Neukirchener Verlag.

TODD, W.N. 1971. The function of patristic writings in the thought of John Calvin. Ann Arbor: University Microfilms.

VAN DER MERWE, N.T. 1982. Calvin, Augustine and Platonism. (In Van der Walt, B.J., ed. Calvinus reformator: his contribution to theology, church and society. Potchefstroom: Institute for Reformational Studies. p. 69-84.)

VAN DER WALT, B.J. 1974. Die natuurlike teologie met besondere aandag aan die visie daarop by Thomas van Aquino, Johannes Calvyn en die "Synopsis Purioris Theologiae": 'n wysgerige ondersoek. Potchefstroom: $\mathrm{PU}$ vir CHO. (Ongepubliseerde D.Phil.-proefskrif.)

VAN DER WALT, B.J. 1979. Die denkdekor van die Reformasie met spesiale verwysing na Calvyn. Potchefstroom: Instituut vir Reformatoriese Studie.

VAN DER WALT, B.J. 1991. The intellectual décor of the Reformation with special reference to Calvin. (In Van der Walt, B.J. Anatomy of reformation: flashes and fragments of a reformational worldview. Potchefstroom: Institute for Reformational Studies. p. 209-256.)

VAN DER WALT, B.J. 2006. The philosophy of D.H. Th. Vollenhoven, with special reference to his historiography of philosophy. Tydskrif vir Christelike wetenskap, 42:35-59.

VAN DER WALT, B.J. 2010a. John Calvin (1509-1564); the father of a transforming Christian worldview. (In Van der Walt, B.J. At home in God's world. Potchefstroom: The Institute for Contemporary Christianity in Africa. p. 80-126.)

VAN DER WALT, B.J. 2010b. John Calvin's struggle to attain a truly biblical view of the human being. (In Van der Walt, B.J. At home in God's world. Potchefstroom: The Institute for Contemporary Christianity in Africa. p. 224-258.) 
VAN DER WALT, B.J. 2010c. A new paradigm for doing Christian philosophy: D.H. Th. Vollenhoven (1892-1978). (In Van der Walt, B.J. At home in God's world. Potchefstroom: The Institute for Contemporary Christianity in Africa. p. 152-182.)

VAN GENDEREN, J. 1965. Calvijns dogmatisch werk. (In Van Genderen, J. Veenhof, C., Nauta, D., Hoge, L.J.M. \& Van der Linde, S. Zicht op Calvijn. Amsterdam: Buijten \& Schipperheijn. p. 9-46.)

VAN 'T SPIJKER, W. 1986a. The influence of Luther on Calvin according to the Institutes. (In Van der Walt, B.J., ed. John Calvin's Institutes, his opus magnum. Potchefstroom: Institute for Reformational Studies. p. 83-105.)

VAN 'T SPIJKER, W. 1986b. The influence of Bucer on Calvin as becomes evident from the Institutes. (In Van der Walt, B.J., ed. John Calvin's Institutes, his opus magnum. Potchefstroom: Institute for Reformational Studies. p. 106-132.)

VAN 'T SPIJKER, W., BALKE, W., EXALTO, K. \& VAN DRIEL, L., reds. 1980. Bij brood en beker: leer en gebruik van het heilig avondmaal in het Nieuwe Testament en in de geschiedenis van de Westerse kerk. Goudriaan: De Groot.

VOLLENHOVEN, D.H. Th. 2005a. De probleemhistorische methode en de geschiedenis van de Wijsbegeerte. Red. door K.A. Bril. Amstelveen: De Zaak Haes.

VOLLENHOVEN, D.H. Th. 2005b. The problem-historical method and the history of philosophy. Ed. by K.A. Bril. Trans. by J. de Kievit, S. Francke, J.G. Friesen \& R. Sweetman. Amstelveen: De Zaak Haes.

VOLLENHOVEN, D.H. Th. 2005c. Isagoge philosophiae/Introduction to philosophy. Ed. by J.H. Kok \& A. Tol. Bilingual edition. Sioux Center: Dordt College Press.

WENDEL, F. 1963. Calvin: the origins and development of his religious thought. Trans. by P. Mairet. London: Collins.

WENDEL, F. 1976. Calvin et l'humanisme. Paris: Presses Universitaires de France.

WILLIAMS, G.H. \& MERGAL, A.M. 1957. Spiritual and Anabaptist writers. Philadelphia: Westminster Press.

ZACHMANN, R.C., ed. 2008. John Calvin and Roman Catholicism: critique and engagement, then and now. Grand Rapids: Baker Academic.

\section{Key concepts:}

Calvin

Christian philosophy

philosophical influences

theological influences

\section{Kernbegrippe:}

Calvyn

Christelike filosofie

filosofiese invloede

teologiese invloede 
